10. Chien S Schmalzer EA, Lee MML, Impelluso T, Skalak R 1983 Role of white blood cells in filtration of blood cells suspensions. Biorheology 20:11-27

11. Gaehtgens P, Schickendantz S 1975 Rheological properties of maternal and neonatal blood. Bibl Anat 13:107-108

12. Gasser C, Willi H 1952 Spontane Innenkoerperbildung bei Milzagenesie. Helvet Paediatr Acta 7:369-382

13. Gatti RA, Muster AJ, Cole RB, Paul MH 1966 Neonatal polycythemia with transient cyanosis and cardio-respiratory abnormalities. J Pediatr 69:10631072

14. Gross GP, Hathaway WE 1972 Fetal erythrocyte deformability. Pediatr Res 6:593-599

15. Hakanson DO, Oh W 1977 Necrotizing enterocolitis and hyperviscosity in the newborn infant. J Pediatr 90:458-461

16. Holroyde CP, Oski FA, Gardner FH 1969 The pocked erythrocyte. Red cell surface alterations in reticuloendothelial immaturity of the neonate. $\mathrm{N} \mathrm{Engl}$ $\mathrm{J}$ Med 281:516-520

17. Holroyde CP, Gardner FH 1970 Acquisition of autophagic vacuoles by human erythrocytes. Physiological role of the spleen. Blood 36:566-575

18. Kent G, Minick OT, Volini FI, Orfei E 1966 Autophagic vacuoles in human red cells. Am J Pathol 48:831-857

19. Linderkamp O, Wu PYK, Meiselman HJ 1982 Deformability of density separated red blood cells in normal newborn infants and adults. Pediatr Res 16:964-968

20. Linderkamp O, Wu PYK, Meiselman HJ 1983 Geometry of neonatal and adult red blood cells. Pediatr Res 17:250-253

21. Macintosh TF, Walker CHM 1973 Blood viscosity in the newborn. Arch Dis Child 48:547-553

22. Markarian M, Jackson JJ 1968 Comparison of the kinetics of clot formation, fibrinogen, fibrinolysis, and hematocrit in pregnant women and adults. Am J Obstet Gynecol 101:593-602

23. Matoth Y, Zaizov R. Varsano I 1971 Postnatal changes in some red cell parameters. Acta Paediatr Scand 60:317-323

24. Mentzer WC 1978 Polycythaemia and the hyperviscosity syndrome in newborn infants. Clin Haematol 7:63-74

25. Neuhausen BS, Rioch DM 1923 The refractometric determination of serum proteins. J Biol Chem 55:353-356

26. Pearson HA 1967 Life-span of the fetal red blood cells. J Pediatr 70:166-171

27. Ratnoff OD, Colopy JE. Pritchard JA 1954 The blood-clotting mechanism during normal parturition. J Lab Clin Med 44:408-415

28. Ratnoff OD, Menzie C 1951 A new method for the determination of fibrinogen in small samples of plasma. J Lab Clin Med 37:316-320

29. Reinhart WH, Chien S 1983 Effects of osmolality on red cell deformability. Physiologist 26:A-107

30. Relier JP, de Gamarra E, de Bethmann O, Savaglio N, Minkowski A 1976 Interet de la mesure du taux de fibrinogene dans les infections neonatales par contamination maternelle. Arch Fr Pediatr 33:109-120

31. Riopel L, Fouron JC, Bard H 1982 Blood viscosity during the neonatal period: the role of plasma and red blood cell type. J Pediatr 100:449-453

32. Riopel L. Fouron JC, Bard H 1983 A comparison of blood viscosity between the adult sheep and newborn lamb. The role of plasma and red blood cell type. Pediatr Res 17:452-455

33. Rosenkrantz TS, Oh W 1982 Cerebral blood flow velocity in infants with polycythemia and hyperviscosity: effects of partial exchange transfusion with Plasmanate. J Pediatr 101:94-98

34. Skalak R, Impelluso T. Schmalzer EA, Chien S 1983 Theoretical modeling of filtration of blood cell suspensions. Biorheology 20:41-56

\title{
New Tools for the Study of Niemann-Pick Disease: Analogues of Natural Substrate and Epstein-Barr Virus-transformed Lymphoid Cell Lines
}

\author{
THIERRY LEVADE, ROBERT SALVAYRE, JEAN-CLAUDE BES, MEYER NEZRI, AND \\ LOUIS DOUSTE-BLAZY \\ Laboratoire de Biochimie Médicale (Faculté de Médecine Purpan) and INSERM U 101, Biochimie des Lipides, \\ Toulouse, France [T.L., R.S., L.D.B.J, Laboratoire de Biologie Médicale (Faculté de Médecine Purpan) \\ Toulouse, France [J.C.B.], and Service de Pédiatrie, Centre Hospitalier d'Aix en Provence, France [M.N.]
}

\begin{abstract}
Acid sphingomyelinase activity was determined in Epstein-Barr virus-transformed lymphoid cell lines (LCL) established from patients affected with Niemann-Pick disease (NPD) using several substrates: sphingomyelin derivatives, radiolabeled $\left[{ }^{14} \mathrm{C} /\right.$ sphingomyelin (SM), fluorescent $N$-(10-(1-pyrene)decanoyl)sphingomyelin $\left(\mathrm{P}_{10}-\mathrm{SM}\right)$ or colored trinitrophenylaminolaurylsphingomyelin, and the chromogenic non-natural substrate 2- $N$-(hexadecanoyl)amino-4-nitrophenylphosphoryl-choline. LCL from NPD Type A and Type B showed a severe deficiency of acid sphingomyelinase determined using either substrate, whereas LCL from normal subjects had
\end{abstract}

Received March 7. 1984: accepted June 22, 1984

Requests for reprints should be addressed to Dr. Thierry Levade, Laboratoire de Biochimie Médicale, Faculté de Médecine Purpan, 37. Allées Jules Guesde, 31000 Toulouse, France.

This research was supported by grants from Institut National de la Santé et de la Recherche Médicale and from Université Paul Sabatier, Toulouse, France. an activity close to that of blood leukocytes. Sphingomyelinase in normal LCL had the same pH optimum (5.0-5.2) and molecular form (pI 5.8) as the enzyme from other sources; identical profiles and activity levels were obtained using the various analogues of sphingomyelin. However, among these derivatives, the assay using $\mathrm{P}_{10^{-}}-\mathrm{SM}$ appeared as the most useful and sensitive for enzymatic diagnosis of NPD. Electron microscopy of NPD LCL demonstrated the lysosomal storage. These results prove the validity of $\mathrm{LCL}$ as an experimental model system for NPD. (Pediatr Res 19:153-157, 1985)

\section{Abbreviations}

LCL, lymphoid cell lines

NPD, Niemann-Pick disease

SM, sphingomyelin

$\mathrm{P}_{10}-\mathrm{SM}, \mathrm{N}-(10-(1-p y r e n e)$ decanoyl)sphingomyelin 
TNPAL-SM, trinitrophenylaminolaurylsphingomyelin HDA-PC, 2- $N$-(hexadecanoyl)amino-4-nitrophenylphosphorylcholine

Niemann-Pick disease is a heterogeneous group of hereditary diseases characterized by accumulation of sphingomyelin in tissues of affected patients (5). Following clinical, genetic, and biological criteria, several types can be separated: five types following Crocker et al. $(5,8)$ or six types according to Neville et al. (26). Only Type A (acute neuropathic form) and Type B (chronic non-neuropathic form) of the Crocker's classification show a severe deficiency of acid sphingomyelinase activity (EC 3.1.4.12) (5). In Type C, contradictory results on sphingomyelinase activity $(6,15,34)$ and recent studies on sphingomyelin metabolism (23) suggest that sphingomyelinase deficiency, if it exists, is not the primary defect. In Types $\mathrm{D}$ and $\mathrm{E}$, sphingomyelinase activity seems generally to be in the normal range $(5,28)$; a new Type $F$ characterized by a heat-labile sphingomyelinase has been recently reported by Schneider et al. (32).

For the detection of acid sphingomyelinase deficiency, several natural or semisynthetic substrates [radiolabeled (5), fluorescent or colored (11), or a synthetic chromogenic analogue $(10,22)]$ can be accurately used. In contrast, synthetic chromogenic or fluorogenic phosphodiesters seem not to be reliable for the diagnosis of sphingomyelinase deficiency because of their hydrolysis by several nonspecific phosphodiesterases $(17,21,25)$.

Experimental studies can be performed using cell cultures. The diploid fibroblast culture is the most commonly used model system but has several disadvantages: limited lifespan and aging (16); modifications of enzyme activities during senescence (27); and difficulties in producing large quantities of cellular material for biochemical studies. In contrast, Epstein-Barr virus-transformed LCL have several advantages: continuous cultures for long periods; minimal changes in phenotypic expression; and the possibility of obtaining a large amount of cellular material due to a short doubling time and the capacity of these cells to grow in suspension culture $(12,27)$. Such lines have been used in the study of several lysosomal disorders $(24,29-31,35)$.

We report in this paper data concerning two new tools (substrates and culture model system) useful for the study of NPD. Enzymatic and ultrastructural studies permit the evaluation of these first LCL established from NPD Types A and B.

\section{MATERIALS AND METHODS}

Chemicals. The different substrates were purchased from: New England Nuclear (Paris) for $\left[{ }^{14} \mathrm{C}\right]$ methylcholine-SM), specific activity $51 \mathrm{mCi} / \mathrm{mmol}$; Sigma (St Louis, MO) for $\mathrm{P}_{10}-\mathrm{SM}$ and TNPAL-SM; and Koch-Light (Colnbrook, U. K.) for HDA-PC.
Ultrodex and Ampholines 3.5-10.0 were supplied from LKB (Bromma, Sweden). RPMI 1640 and fetal calf serum were from Gibco (Grand Island, NY) and other reagents were from Merck (Darmstadt, F. R. G.).

Long term lymphoid cell lines. These were established from blood lymphocytes of normal or sick subjects after incubation with the $\mathrm{B}_{95}$ strain of Epstein-Barr virus as previously reported $(30,31)$. The different LCL corresponded to: Be, normal adult; $\mathrm{C}_{49}$, normal newborn; E1G, child with NPD Type A, and Par and Alb, NPD Type B. The transformed cells were cultured in RPMI 1640 as described in Ref. 31, collected 3 days after medium change, and stored at $-70^{\circ} \mathrm{C}$ until use. Informed consent was obtained from all human patients.

Determination of molecular forms. Analysis of sphingomyelinase was carried out using preparative electrofocusing as previously reported for hexosaminidase (30).

Enzyme assays (Table 1). Cells were homogenized by sonication (three cycles of $15 \mathrm{~s}$ ) on Triton X-100, $0.25 \%$. Sphingomyelinase activity was tested using SM according to Wenger (36), using HDA-PC as previously reported (22) and using $\mathrm{P}_{10}-\mathrm{SM}$ and TNPAL-SM according to Gatt et al. (11). The enzymatic reaction with these two latter substrates was linear at least for 2 $\mathrm{h}$ and up to $0.5 \mathrm{mg}$ of protein $/ \mathrm{ml}$ of assay. Protein concentration was determined using the method of Bradford (4) with serum albumin as standard.

Analysis of phospholipids in LCL. Lipids were extracted from the cell samples by the method of Folch et al. (9). Phospholipids were separated by thin layer chromatography on Silica Gel G (Merck) with a solvent system of chloroform/methanol/water, 100:42:6 ( vol/vol/vol). The content of different phospholipids was determined by phosphorus assay (7).

Electron microscopy. Cellular ultrastructure was studied as previously described (1).

\section{RESULTS}

Table 2 shows the sphingomyelinase activities determined with the different analogues of sphingomyelin in normal and NPD LCL. In LCL from normal subjects, there was no difference in activity levels using either substrate. In LCL from NPD Type A or B, sphingomyelinase activity was severely deficient. The three synthetic analogues of sphingomyelin were also reliable for demonstration of the sphingomyelinase deficiency.

These analogues were tested to determine sphingomyelinase activity as a function of pH (Fig. 1); normal LCL showed a pH optimum between 5.0 and 5.2. The enzymatic values obtained at acidic $\mathrm{pH}$ were practically superimposable on those by radioassay. At neutral pH (7.5-8.0), slight activity was observed with $\mathrm{SM}$ and $\mathrm{P}_{10}$-SM (the sensitivity of the assay using TNPAL-SM was not sufficient to determine it); at this $\mathrm{pH}$, HDA-PC was not hydrolyzed, in agreement with previous results in brain (20).

Table 1. Assays of sphingomyelinase in LCL

\begin{tabular}{|c|c|c|c|c|}
\hline Assay & SM & $\mathrm{P}_{10}-\mathrm{SM}$ & TNPAL-SM & HDA-PC \\
\hline \multicolumn{5}{|c|}{ Substrate concentrations $\left(\mathrm{mmol} \cdot\right.$ liter $\left.^{-1}\right)$} \\
\hline Sphingomyelin & 0.4 & 0.28 & 0 & 0 \\
\hline Labeled substrate & $2000 \mathrm{dpm} \cdot \mathrm{nmol}^{-1}$ & 0.015 & 0.3 & 14 \\
\hline Buffer $\left(\mathrm{mol} \cdot 1^{-1}\right)$ & 0.15 & 0.25 & 0.1 & 0.1 \\
\hline Protein requirement $\left(\mathrm{mg} \cdot \mathrm{ml}^{-\mathrm{i}}\right)$ & $0.2-0.5$ & $0.2-0.5$ & $0.2-0.5$ & $1-4$ \\
\hline Final volume $(\mathrm{ml})$ & 0.1 & 0.2 & 0.2 & 0.1 \\
\hline Incubation time $(\mathrm{min})$ & 90 & 120 & 90 & 120 \\
\hline \multirow[t]{2}{*}{ Extraction system* } & $\mathrm{C} / \mathrm{M} / \mathrm{W}$ & $\mathrm{I} / \mathrm{H} / \mathrm{W} / \mathrm{SA}$ & $\mathrm{I} / \mathrm{H} / \mathrm{W} / \mathrm{SA}$ & $\mathrm{EA} / \mathrm{I} / \mathrm{G}$ \\
\hline & $2: 1: 0.6$ & $1: 1: 1: 0.015$ & $1: 1: 1: 0.015$ & $5: 1: 5$ \\
\hline Molar extinction coefficient & & & 10000 & 10000 \\
\hline Assay sensitivity (pmol/assay) & $20-40$ & $60-100$ & $500-1000$ & $500-1000$ \\
\hline References & 20,36 & 11 & 11 & 20,22 \\
\hline
\end{tabular}

* The measured product of the enzyme reaction was extracted in the upper phase of each biphasic system. Solvents were: C, chloroform; $\mathrm{M}$, methanol; W, water; I, isopropanol; H, heptane; SA, sulfuric acid; EA, ethyl acetate; and G, glycine buffer, pH $10.5\left(0.2 \mathrm{~mol}^{-l i t e r^{-1}}\right)$. 
Lymphoid cell extracts solubilized in Triton X-100 were subjected to isoelectric focusing (Fig. 2): in cells from normal subjects, only one peak (pI 5.8) was observed using the derivatives of natural substrates (radioactive, fluorescent, or colored) or the non-natural compound, HDA-PC. Again, enzyme activities using either substrate were very similar. In LCL from NPD Types $\mathrm{A}$ and $\mathrm{B}$, no peak of sphingomyelinase activity was detected.

Table 2. Acid sphingomyelinase activity $\left(n m o l \cdot h^{-1} \cdot m g^{-1}\right)$ in $L C L$ from normal subjects and from NPD patients using natural substrate and various analogues of sphingomyelin*

\begin{tabular}{|c|c|c|c|c|}
\hline Cell line & SM & $\mathrm{P}_{10}-\mathrm{SM}$ & TNPAL-SM & HDA-PC \\
\hline \multicolumn{5}{|l|}{ Normal subjects } \\
\hline Be (adult) & $\begin{array}{c}10.3 \\
(7.5-12.5)\end{array}$ & $\begin{array}{c}10.5 \\
(8.0-11.0)\end{array}$ & $\begin{array}{c}8.9 \\
(8.0-10.0)\end{array}$ & $\begin{array}{c}8.0 \\
(6.5-11.5)\end{array}$ \\
\hline $\mathrm{C}_{49}$ (newborn) & $\begin{array}{c}8.5 \\
(7.5-10.5)\end{array}$ & $\begin{array}{c}9.7 \\
(9.0-12.0)\end{array}$ & $\begin{array}{c}9.5 \\
(7.5-9.8)\end{array}$ & $\begin{array}{c}10.0 \\
(7.5-13.0)\end{array}$ \\
\hline \multicolumn{5}{|l|}{ NPD patients } \\
\hline E $1 G$ (type A) & $\begin{array}{c}0.8 \\
(0.0-1.8)\end{array}$ & $\begin{array}{c}0.4 \\
(0.0-1.2)\end{array}$ & $\begin{array}{c}0.1 \\
(0.0-0.2)\end{array}$ & $\begin{array}{c}0.9 \\
(0.0-2.1)\end{array}$ \\
\hline Par (type B) & $\begin{array}{c}1.6 \\
(0.0-2.0)\end{array}$ & $\begin{array}{c}1.1 \\
(0.0-1.8)\end{array}$ & $\begin{array}{c}0.3 \\
(0.0-0.5)\end{array}$ & $\begin{array}{c}1.0 \\
(0.0-1.8)\end{array}$ \\
\hline Alb (type B) & $\begin{array}{c}1.0 \\
(0.6-1.9)\end{array}$ & $\begin{array}{c}0.9 \\
(0.0-1.7)\end{array}$ & $\begin{array}{c}0.2 \\
(0.0-0.4)\end{array}$ & $\begin{array}{c}0.9 \\
(0.0-2.0)\end{array}$ \\
\hline
\end{tabular}

* Activity is the mean of 3 to 11 determinations on different cell batches.

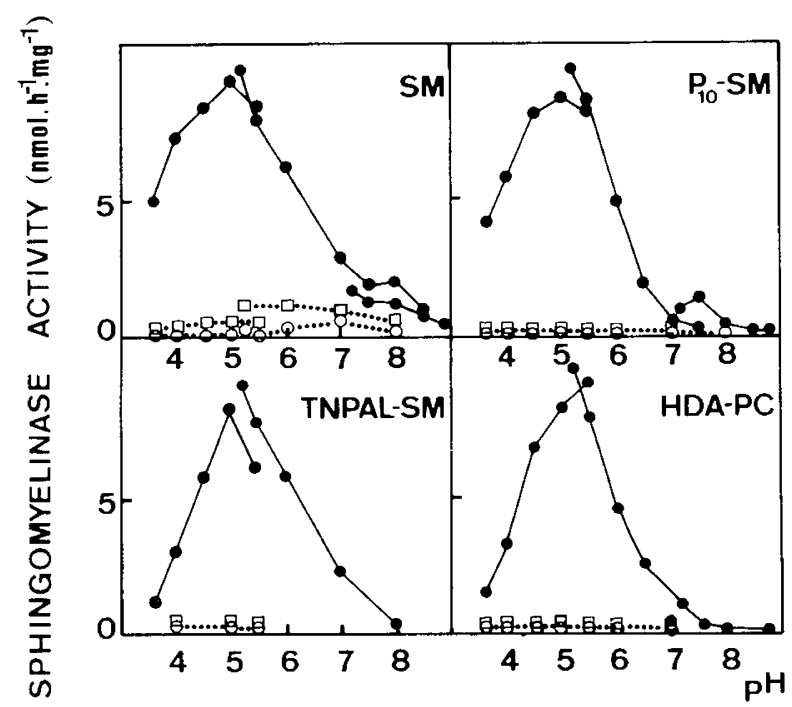

Fig. 1. Effect of $\mathrm{pH}$ on sphingomyelinase activity in LCL. Sphingomyelinase activity was tested in LCL from normal subjects (-๑) and from patients affected with NPD Type A (line E1G, O .... ) and Type B (line Par, $\square \ldots \ldots \square$ ) using the various substrates (for abbreviations, see "Materials and Methods"). Assays were performed as described in the text, using the following buffers $(0.1 \mathrm{M})$ ): sodium acetate buffer ( $\mathrm{pH} 3.6-5.5)$, Tris-maleate buffer ( $\mathrm{pH} 5.2-8.5)$, and Tris- $\mathrm{HCl}$ buffer ( $\mathrm{pH}$ 7.2-9.0)
Total phospholipid content approximated $120 \mathrm{nmol} \cdot \mathrm{mg}$ protein $^{-1}$ in normal LCL; these results agree with those reported by Gottfried in cultured lymphoid cells (13). In NPD LCL, total phospholipid amount varied from 210 to $280 \mathrm{nmol} \cdot \mathrm{mg}$ protein $^{-1}$. In contrast to the constant amount of phosphatidylcholine, the amount of sphingomyelin was increased by 3 to 6 times in NPD LCL (Table 3).

Ultrastructural investigations of LCL from NPD showed an abnormal presence of electron-dense intracytoplasmic inclusions (Fig. 3b) compared to normal cell lines (Fig. 3a). High resolution micrographs demonstrated that the granules were made up of pleiomorphic material. The major component exhibits alternating light and dark bands. This results from the organization of the material into irregular concentric lamellae (Fig. 3c). These osmiophilic bodies are similar to those found in noncultured biopsy liver specimens of NPD patients (not shown).

\section{DISCUSSION}

The aim of this work was (i) to demonstrate the valididy of NPD LCL as a new experimental model system for enzymatic studies of this disease, and (ii) to compare the reliability of various analogues of sphingomyelin for diagnosing sphingomyelinase deficiency.

The validity of LCL as a model of NPD was proved enzymatically and ultrastructurally. First, sphingomyelinase in normal LCL seems to be not modified by Epstein-Barr virus transfor-

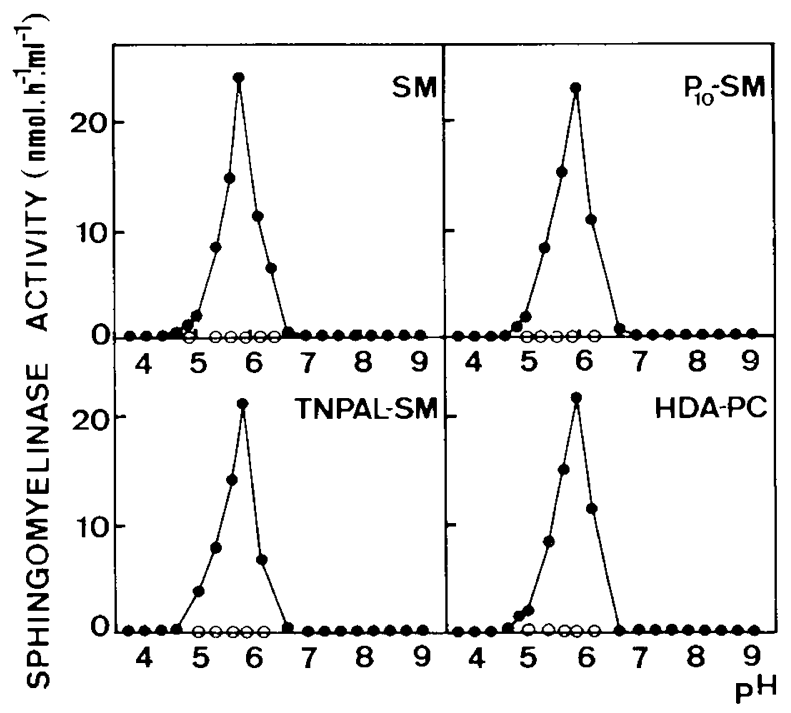

Fig. 2. Electrofocusing profiles of acid sphingomyelinase in LCL from normal subjects and from NPD patients. Sphingomyelinase activity (expressed as $\mathrm{nmol} / \mathrm{h} / \mathrm{ml}$ of fraction) was tested in LCL from normal subjects (line Be, - $\longrightarrow$ ) and from NPD Type A or Type B patients (lines $E 1 G$ or Par, $O \ldots . .0$ ). The Triton extracts were prepared from about $500 \times 10^{6}$ cells and $15 \mathrm{mg}$ of protein of $220,000 \times g$ supernatant fluid were applied on the granulated gel. Assays were performed as described in the text.

Table 3. Sphingomyelin levels in $L C L^{*}$

\begin{tabular}{cccc}
\hline Cell line & $\begin{array}{c}\text { Protein } \dagger \\
\left(\mathrm{mg} \cdot \mathrm{ml}^{-1}\right)\end{array}$ & $\begin{array}{c}\text { Phosphatidylcholine } \\
\text { (nmol phosphorus/mg protein) }\end{array}$ & $\begin{array}{c}\text { Sphingomyelin } \\
\text { (nmol phosphorus/mg protein) }\end{array}$ \\
\hline Normal subjects & & 51 & 17 \\
Be (adult) & 19.5 & 79 & 16 \\
C49 (newborn) & 13.6 & 63 & 55 \\
NPD patients & 6.8 & 94 & 90 \\
E1G (type A) & 4.4 & 102 & 71 \\
Par (type B) & 2.1 & & \\
Alb (type B) & & & \\
\hline
\end{tabular}

* All determinations were done in duplicate.

$\dagger$ The number of cells was respectively $100 \times 10^{6}, 50 \times 10^{6}$, and $20 \times 10^{6}$ for Be and $\mathrm{C}_{49}, \mathrm{E} 1 \mathrm{G}$ and Par, and Alb. 

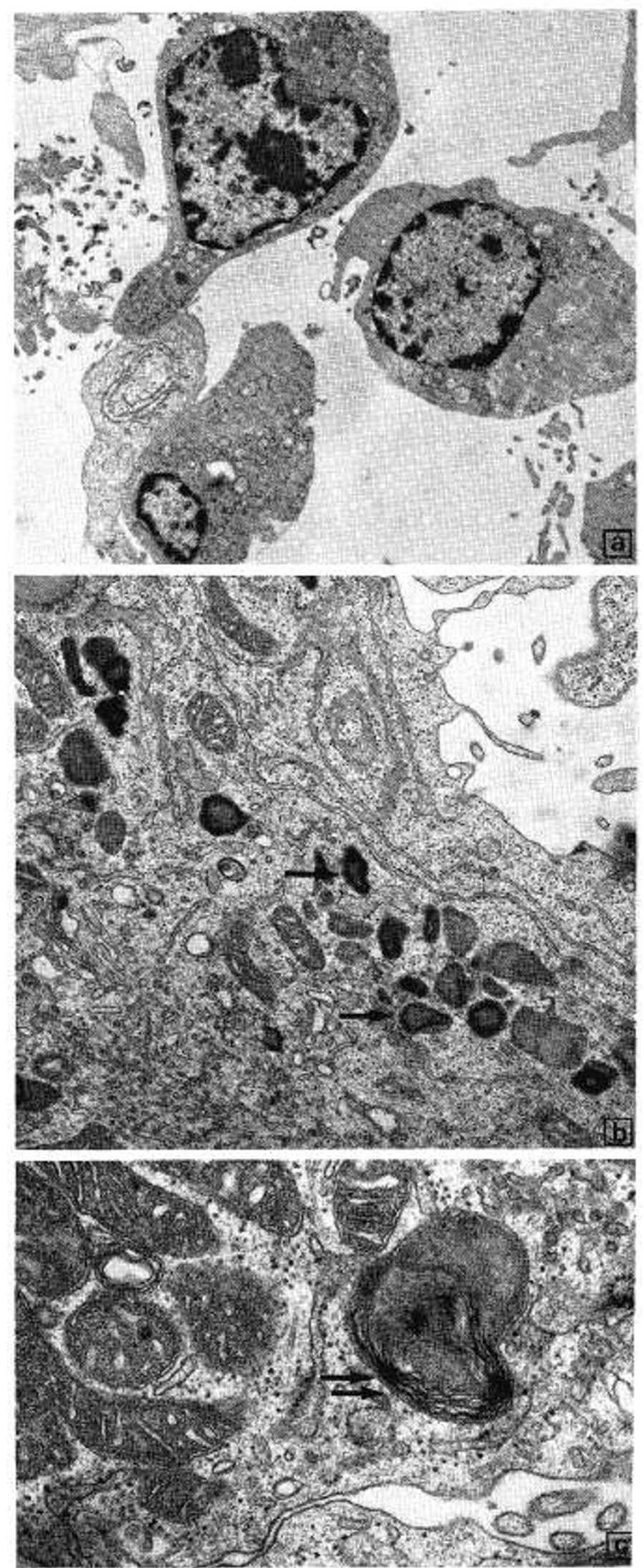

Fig. 3. Electron micrographs of LCL. $a$, established from normal subject (line $\mathrm{Be}$ ); $b$ and $c$, established from NPD patient (line Par). Note numerous irregular whorled cytoplasmic inclusions $(\rightarrow)$ corresponding to distended lysosomes which contain disordered, dense lipid lamellae $(\rightarrow)$ separated by clear, electron-empty zones. $a, \times 3,500 ; b, \times 22,500 ; c$, $\times 45,000)$. mation since it shows the same $\mathrm{pH}$ optimum as in other cells ( 3 , 14,37 ) or tissues $(33)$. Activity levels in normal LCL were slightly higher than in blood leukocytes $(3,14,21,37)$. Moreover, LCL have only one molecular form (pI 5.8): these results agree with those reported by the same procedures on blood leukocytes, lymphocytes, and human brain (19). We did not observe the minor molecular forms described by Callahan et al. (6) or Besley (2); these differences could be due to the different tissue origin and different electrofocusing technique (on thin layer in our case, on column for other authors). Secondly, LCL appear to be a useful model for NPD; indeed, LCL from affected patients showed a severe sphingomyelinase deficiency (Table 2; Figs. 1 and 2). This deficiency explains the cytoplasmic storage of abnormal osmiophilic material similar to myelin-like structures at the electron microscopic level (Fig. 3) as reported in tissues (5).

Moreover, the nature of these amphiphilic lipids was specified by the phospholipid analysis that showed a sphingomyelin storage in NPD LCL (Table 3). However, this accumulation is less than in the tissues of patients, probably because of the absence of contribution by exogenous sphingomyelin (in contrast to the macrophage cells in the organism) and a short doubling time of LCL.

Several analogues of sphingomyelin have also been tested on LCL for enzymatic diagnosis of NPD without the use of radioactivity. We compared (Table 1) the assays using the new derivatives of sphingomyelin synthesized by Gatt et al. (11) and the assay using the chromogenic analogue HDA-PC; methylumbelliferyl-derived phosphodiesters have been previously shown as nonspecific for sphingomyelinase determination (21).

The linearity of $\mathrm{P}_{10}$-SM and TNPAL-SM hydrolysis as a function of protein concentration was very similar to that reported for fibroblasts and amniotic cells (11). On the other hand, the similarities of the activity levels obtained using the new substrates and using radiolabeled substrate or HDA-PC are consistent with the data of Gatt et al. (11). The specificity of these derivatives is demonstrated by the fact that $\mathrm{pH}$ optimum curves and electrofocusing profiles are superimposable on those of natural substrate, and by the fact that they are able to show the sphingomyelinase deficiency in NPD LCL. Ranges of enzyme activity in various cell batches were similar when using natural or synthetic substrate. Consequently, these substrates can be used readily for sphingomyelinase assay and NPD diagnosis.

However, we will discuss their advantages and disadvantages in comparison to natural substrate. The radiolabeled substrate is specific but requires a radiometric procedure, and it is subject to decomposition with time (18). The chromogenic compound HDA-PC provides an easy assay, specific for acid sphingomyelinase (20) but a good product extraction system is essential to eliminate possible interference by hemoglobin (22). However, this non-natural chromogenic substrate gives a relatively insensitive assay. The derivatives recently synthesized by Gatt allow a rapid assay of sphingomyelinase using small quantities of cellular material and a convenient fluorometric or spectrometric determination. These analogues are hydrolyzed by both acid and neutral sphingomyelinases (11). However, the fluorometric assay using $\mathrm{P}_{10}-\mathrm{SM}$ is much more sensitive than that using TNPAL$\mathrm{SM}$; thus, $\mathrm{P}_{10}$-SM can be used 20 -fold-diluted whereas TNPALSM must be used pure (thus it is more expensive).

Our present results indicate that the above substrates can be used to determine acid sphingomyelinase activity. However, the fluorescent assay using $\mathrm{P}_{10}-\mathrm{SM}$ seems to be the most useful, reliable and sensitive assay. In the same way as these substrates constitute a new tool for NPD diagnosis, LCL from NPD represent a new experimental model system for this lysosomal storage disorder. We are now investigating the metabolic features of this model.

Acknowledgments. The authors thank Mrs. Thérèse Perruchot and Michèle Vuillaume for culturing the cells, and Mrs. Yvette Jonquière for reading the English manuscript. 


\section{REFERENCES}

1. Bes JC, Salvayre R, Caratero C, Maret A, Icart J, Soleilhavoup JP, Planel H 1983 Ultrastructural findings on an Epstein-Barr virus transformed lymphoid cell line from a Fabry patient. Biol Cell 47:247

2. Besley GTN 1977 Sphingomyelinase defect in Niemann-Pick disease, type C, fibroblasts. FEBS Lett 80:71

3. Besley GTN 1978 Studies on sphingomyelinase activity in cultured cells and leucocytes. J Inherit Metab Dis 1:29

4. Bradford MM $1976 \mathrm{~A}$ rapid and sensitive method for the quantitation of microgram quantities of protein utilizing the principle of protein-dye binding. Anal Biochem 72:248

5. Brady RO 1983 Sphingomyelin lipidoses: Niemann-Pick disease. In: Stanbury JB, Wyngaarden, JB, Fredrickson DS, Goldstein JL, Brown MS (eds) The Metabolic Basis of Inherited Disease, 5th ed. McGraw-Hill, New York, p 831

6. Callahan JW, Khalil M 1976 Sphingomyelinases and the genetic defects in Niemann-Pick disease. In Volk BW, Schneck L (eds) Current Trends in Sphingolipidoses and Allied Disorders, Vol 68. Plenum Publ. Corp., New York, p 367

7. Chen PS, Toribara TY, Warner H 1956 Microdetermination of phosphorus. Anal Chem 18:1756

8. Crocker AC 1961 The cerebral defect in Tay-Sachs disease and Niemann-Pick disease. J Neurochem 7:69

9. Folch J, Lees M, Sloane Stanley GN 1957 A simple method for the isolation and purification of total lipids from animal tissues. J Biol Chem 226:497

10. Gal AE, Brady RO, Barranger JA, Pentchev PG 1980 The diagnosis of type A and type B Niemann-Pick disease and detection of carriers using leukocytes and a chromogenic analogue of sphingomyelin. Clin Chim Acta 104:129

11. Gatt S, Barenholz Y, Goldberg R. Dinur T, Besley G, Leibovitz-Ben Gershon Z, Rosenthal J, Desnick RJ, Devine EA, Shafit-Zagardo B, Tsuruki F 1981 Assay of enzymes of lipid metabolism with colored and fluorescent derivatives of natural lipids. Methods Enzymol 72:351

12. Glade PR. Beratis NG 1976 Long-term lymphoid cell lines in the study of human genetics. Prog Med Genet I:

13. Gottfried EL 1971 Lipid patterns in human leukocytes maintained in longterm culture. J Lipid Res 12:531

14. Hardy B, Hoffman J, Neri A 1982 Lymphocyte enzymes in the detection of Niemann-Pick carriers. Biomedicine 36:372

15. Harzer K. Anzil AP. Schuster I 1977 Resolution of tissue sphingomyelinase isoelectric profile in multiple components is extraction-dependent: evidence for a component defect in Niemann-Pick disease type $\mathrm{C}$ is spurious. $J$ Neurochem 29:1155

16. Hayflick L, Moorhead PS 1961 The serial cultivation of human diploid cell strains. Exp Cill Res 25:585

17. Jones CS, Davidson DJ, Callahan JW 1982 Complex kinetics of bis(4-methylumbelliferyl)phosphate and hexadecanoyl(nitrophenyl)phosphorylcholine hydrolysis by purified sphingomyelinase in the presence of Triton X-100. Biochim Biophys Acta 701:261

18. Kanfer JN, Williams M 197I Radiochemical decomposition of $\mathrm{N}^{-14} \mathrm{CH}_{3}$ labeled sphingomyelin. Chem Phys Lipids 6:121

19. Levade T 1982 Contribution à l'étude des sphingomyélinases cérébrales humaines. Thèse de Doctorat en Médecine, Toulouse, No. 421

20. Levade T, Salvayre R. Douste-Blazy L 1983 Comparative hydrolysis of sphingomyelin and 2-N-(hexadecanoyl)-amino-4-nitrophenyl phosphorylcholine by normal human brain homogenate at acid and neutral pH. J Neurochem
40:1762

21. Levade T, Salvayre R, Lenoir G, Douste-Blazy L 1984 Sphingomyelinase and non-specific phosphodiesterase activities in Epstein-Barr virus-transformed lymphoid cell lines from Niemann-Pick disease A, B, and C. Biochim Biophys Acta 793:321

22. Levade T, Salvayre R, Sicre J. Douste-Blazy L 1983 An improved method excluding hemoglobin interferences for lysosomal hydrolase assays using colorimetric synthetic substrates, 2-(N-hexadecanoylamino)-4-nitrophenol derivatives. Anal Biochem 130:521

23. Mazière JC, Mazière C, Mora L, Routier JD, Polonovski J 1982 In situ degradation of sphingomyelin by cultured normal fibroblasts and fibroblasts from patients with Niemann-Pick disease type $A$ and C. Biochem Biophys Res Commun 108:1101

24. Minami R, Watanabe $Y$, Kudoh T, Suzuki M Oyanagi K, Orii T, Nakao T 1978 Lysosomal acid hydrolases in established lymphoblastoid cell lines, transformed by Epstein-Barr virus, from patients with genetic lysosomal storage diseases. Hum Genet 44:79

25. Nègre A, Salvayre R, Maret A, Douste-Blazy L 1981 Phosphodiestérases non spécifiques des leucocytes, des plaquettes sanguines et du sérum humains. Biomedicine 35:128

26. Neville BGR, Lake BD. Stephens R, Sanders MD 1973 A neurovisceral storage disease with vertical supranuclear ophtalmoplegia and its relationship to Niemann-Pick disease. A report of nine patients. Brain 96:97

27. Povey MS 1976 The biochemical genetics of human lymphoblastoid cell lines. Ph.D. thesis, London University

28. Rao BG, Spence MW 1977 Niemann-Pick disease type D: lipid analysis and studies on sphingomyelinases. Ann Neurol 1:385

29. Salvayre R, Maret A, Bes JC, Lenoir G, Nègre A. Douste-Blazy L 1983 Les lignées lymphoblastoides transformées par virus Epstein-Barr. Modèle cellulaire en culture pour l'étude des enzymopathies lysosomiques. Ann Biol Clin 41:299

30. Salvayre R. Maret A, Nègre A, Lenoir G, Vuillaume M, Icart J, Didier J, Douste-Blazy L 1983 Molecular forms of $\beta$-N-acetylhexosaminidase in Epstein-Barr virus-transformed lymphoid cell lines from normal subjects and patients with Tay-Sachs disease. Eur J Biochem 133:627

31. Salvayre R, Nègre A, Maret A, Lenoir G, Douste-Blazy L 1981 Separation and properties of molecular forms of $\alpha$-galactosidase and $\alpha$-N-acetylgalactosaminidase from blood lymphocytes and lymphoid cell lines transformed by Epstein-Barr virus. Biochim Biophys Acta 659:445

32. Schneider EL, Pentchev PG, Hibbert SR, Sawitsky A, Brady RO 1978 A new form of Niemann-Pick disease characterized by temperature-labile sphingomyelinase. J Med Genet 15:370

33. Sloan HR 1972 Sphingomyelinase from human liver (sphingomyelin choline phosphohydrolase). Methods Enzymol 28:874

34. Vanier MT, Revol A. Fichet M 1980 Sphingomyelinase activities of various human tissues in control subjects and in Niemann-Pick disease. Development and evaluation of a microprocedure. Clin Chim Acta 106:257

35. Watanabe Y, Minami R 1981 Lymphoblastoid cell lines transformed by Epstein-Barr virus in the enzymatic study of hereditary lysosomal storage diseases. Tohoku J Exp Med 134:229

36. Wenger DA 1977 Niemann-Pick disease. In Glew RH, Peters SP (eds) Practical Enzymology of the Sphingolipidoses. Alan R Liss, New York, p 39

37. Zitman D Chazan S, Klibansky C 1978 Sphingomyelinase activity levels in human peripheral blood leukocytes, using $\left({ }^{3} \mathrm{H}\right)$ sphingomyelin as substrate: study of heterozygotes and homozygotes for Niemann-Pick disease variants. Clin Chim Acta 86:37 